\title{
Personal Troubles and Public Issues: A Sociological Imagination of Black Athletes’ Experiences at Predominantly White Institutions in the United States
}

\author{
Joseph N. Cooper \\ Department of Kinesiology, International Center for Sport Management, University of Georgia, Athens, USA \\ Email: joeycoop@uga.edu
}

Received April 28 $8^{\text {th }}$, 2012; revised May 28 $8^{\text {th }}$, 2012; accepted June $7^{\text {th }}, 2012$

\begin{abstract}
The purpose of this paper is to provide a socio-historical examination of Black athletes' experiences at predominantly White institutions (PWIs) and connect these experiences with the broader social issues facing Blacks in the United States (US). Historically, the prevalence of racism within the US has contributed to the oppression, discrimination, and limited upward mobility of Blacks. In the US, racist beliefs have been institutionalized formally through federal and state laws as well as informally through social practices and norms. Using Mills' (1959) sociological imagination as a conceptual framework, the author provides a critical examination of the connection between the personal biographies of Black athletes at PWIs and the historical public issues facing Blacks in the US as documented in scholarly and relevant literatures. Understanding the connection between biographies and history allows for a more holistic understanding of the root causes of these personal troubles and public issues. Common themes in the literature that will be highlighted and addressed include experiences with racial discrimination/social isolation, academic neglect, economic deprivation, and limited leadership opportunities.
\end{abstract}

Keywords: Black Athletes; Sociological Imagination; Racism; Predominantly White Institutions

\section{Introduction}

"Man is a social and an historical actor who must be understood, if at all, in close and intricate interplay with social and historical structures” (Mills, 1959: p. 158)

Sports represent a microcosm of society. This popular phrase refers to the fact that sports do not operate as a vacuum separate from society, but rather as one part of the whole (Coakley, 2009; Edwards, 1973a, 1973b; Sage, 1998). Often times sports reinforce the dominant power structures and social inequalities present within a society. More specifically, Black participation in sports in the United States (US) has always been a contested terrain that reflected the state of Black Americans within the broader US society. A prime example is the exclusion of Black athletes from intercollegiate athletics at predominantly White institutions (PWIs) and the concurrent exclusion of Blacks from mainstream society (e.g. politics, education, business, etc.) from the early seventeenth century through the late nineteenth century (Wiggins \& Miller, 2003). PWIs did not integrate Black athletes until the early twentieth century (Wiggins, 2000). During this period, only a limited number of outstanding Black athletes (e.g. Paul Robeson, Jesse Owens, and Jackie Robinson) were admitted to these institutions primarily for their athletic abilities. Consequently, these Black athletes encountered unwelcoming environments that ambivalently applauded their athletic prowess, yet simultaneously viewed them as intellectually and socially inferior (Edwards, 1994; Hawkins, 2010; Lapchick, 1991; Sailes, 2010; Sellers, 2000).

A key factor associated with these challenges, as it relates to Black athletes, has been the historical and contemporary practice of racism in the US (Brooks \& Althouse, 2000; Coakley,
2009; Edwards, 1973b; Sage, 1998; Sailes, 2010; Wiggins \& Miller, 2003). In order to understand how racism operates within the US society it is important to define race and racism. Helms (1994) defined race as a "reified, socially defined categorization system that has become the basis of one form of social identity" (pp. 294-295). In the US, phenotypical features such as skin color, facial features, hair texture, and body structures have been used as social markers to label and identify people of the Black racial group. Consequently, the social practice of racism emerged through the promulgation of negative stereotypes based on racial categories. Coakley (2009) defines racism as "attitudes, actions, and policies based on the belief that people in one racial category are inherently superior to people in one or more other categories” (p. 281). Both Black athletes at PWIs and Blacks in the broader US society faced multiple levels of racism (e.g. institutional, cultural, and individual), which contributed to negative life outcomes (e.g. limited educational opportunities, lower career mobility, poorer health outcomes, higher rates of incarceration, etc. (Hawkins, 2010).

Furthermore, the practice of racism against Blacks has been commonplace in the US since 1619 when European settlers enslaved Black Africans on US soil primarily for economic exploitation (Hine, Hine, \& Harrold, 2006). Consequently, racism remains deeply entrenched in US social institutions (e.g. political, economic, educational and religious) and cultural practices (e.g. sport, music, and art), thus creating a socially stratified society where Blacks are viewed and treated as inferior to Whites (Coakley, 2009; Sage, 1998; Wiggins \& Miller, 2003). The pervasive racism against Blacks throughout the US has contributed to negative social experiences in various social 
settings including post-secondary institutions (e.g. PWIs). Thus, understanding the history of racism against Blacks in the US provides a more comprehensive socio-historical context for the critical examination and understanding of Black athletes' experiences at PWIs.

\section{Sociological Imagination: A Framework for the Examination of Racism in the United States}

According to C. Wright Mills (1959), the sociological imagination is a process of understanding the connection between biography and history. Biographies occur on an individual level whereas history involves a culmination of events on a structural level. Mills' (1959) contends biographies and history are inextricably intertwined. The link between biographies and history manifests in the emergence of personal troubles and public issues. Personal troubles are events that "occur within the character of the individual and within the range of his immediate relations with others" (Mills, 1959: p. 8). An example of a personal trouble is a Black athlete's motivation or lack thereof to be engaged academically at a PWI. Contrarily, public issues are "matters that transcend these local environments of the individual and the range of his inner life" (Mills, 1959: p. 8). An example of a public issue is the persistent academic achievement gap between Blacks and Whites within the US educational system (ETS, 2011; NCES, 2007; Nettles \& Perna, 1997a, 1997b). It is the promise of the sociological imagination that enables individuals to understand the connection between personal biographies and broader socio-historical realities in order to address both problems rooted in structural arrangements (Mills, 1959).

For the purposes of this paper, the sociological imagination will be used as a critical lens to examine the history of a specific group of people (Blacks) in a specific context (US). However, the author acknowledges several scholars have different interpretations of the appropriate use of the sociological imagination in social science inquiry (Dandaneau, 2000; Denzin, 1990; Gitlin, 2000; Richardson, 1997; Spencer, 2010). For example, one interpretation suggests Mills' (1959) intention for using the sociological imagination was to focus on the structural arrangements across international societies. From this perspective, prevalent issues such as racism, sexism, and classism would be dissected and contrasted within a global context. Another view, which the author advocates, is the notion that the sociological imagination serves as useful tool to examine structural arrangements and broad social problems within a specific context. These perspectives are not inherently contradictory, rather interpreted and applied in a different fashion. This idea of multiple interpretations is consistent with the social constructivist epistemological stance held by the author (Denzin \& Lincoln, 2005; Lincoln \& Guba, 2000). Furthermore, this perspective supports the idea that the sociological imagination can apply to any societal context where historical events and structural arrangements influence the lived experiences of individuals within a given society.

The contextualization of Black athletes' experiences at PWIs within a broader socio-historical narrative of Blacks in the US allows for an in-depth analysis of inequitable US structural arrangements. More specifically, the comparison of the collective biographies of Black athletes and historical events associated with Blacks in the US draws attention to widespread structural inequalities pervasive throughout US social institutions (e.g. political, economic, judicial, educational, and religious). Similar to other facets of US society, intercollegiate athletics serves as a site for the reinforcement of dominant power structures (Coakley, 2009). The ability to analyze the relationship between the personal troubles of Black athletes at PWIs and the historical impact of public issues on Blacks in the US constitutes an effort to deconstruct the dominant power structure, which oppresses them (McDonald \& Birrell, 1998; Spencer, 2010). The deconstruction of the dominant power structure, which in the US is rooted in the ideology of White supremacy, will enable new structures to emerge that empower those who are oppressed (DuBois, 1996).

Both Blacks with the US and Black athletes at PWIs have experienced similar challenges as result of their social status. These similar experiences stem from the fact that Blacks have historically been subject to racist beliefs, which view them as innately inferior to Whites (DuBois, 1996; Helms, 1994; Hine et al., 2006). A review of relevant literature revealed four common themes shared between both groups: 1) racial discrimination/social isolation; 2) academic neglect; 3) economic deprivation; and 4) limited leadership opportunities.

\section{Intersection \#1: Racial Discrimination/Social Isolation}

A major issue facing both Blacks in the broader US and Black athletes at PWIs is the experiences with racial discrimination and social isolation. At both the macro (US) and micro (PWI) level, Blacks constitute a minority group. As minorities, Blacks have experienced environments and social norms that are constructed for the dominant White culture (DuBois, 1996). Understanding the connection between the socio-historical experiences of Black in the US and the experiences of Black athletes at PWIs provides a more comprehensive examination of public issue and personal trouble of racial discrimination/social isolation (Mills, 1959).

\section{Public Issue}

Historically, a public issue facing Blacks in the US society has been the practice of racial discrimination. Racism in the US has been used a social marker used to justify various forms of discrimination, subordination, and injustice against Blacks (Helms, 1994; Hine et al., 2006). Although other racial and ethnic minority groups have experienced similar forms of oppression, the experiences of Blacks are unique. Black Americans are the only racial group in the US to be subjected to an extended period of slavery and to have de jure (legalized) segregation laws passed against them that were fully supported by the Supreme Court (Bell, 1992; Sage, 2000; Wilson, 1996). In nearly every facet of American society (e.g. economic, educational, political, health, and judicial), Blacks have historically been and continue to be significantly disadvantaged (ETS, 2011; Hine et al., 2006).

Prior to 1865 , Blacks were legally enslaved and disallowed citizenship under the US constitution. Blacks were enslaved solely based skin color. Following the Emancipation Proclamation of 1865, Blacks were liberated from legalized slavery, yet racially discriminatory practices and attitudes remained prevalent throughout the US. The idea of White supremacy was the underlying ideology rooted in these racially discriminatory 
beliefs, which was supported by theories of scientific racism and social Darwinism (Comstock, 1912; Jensen, 1969; Jones, 1998; Stone, 1908a; Van Evrie, 1870). This ideology purported the misconception that Whites were innately superior to Blacks, thus justifying their enslavement, mistreatment, and subjugation in all aspects of US society (DuBois, 1996; Helms, 1994; Hine et al., 2006).

Similar to racial discrimination, Blacks within the US have also been subject to social isolation (Hine et al., 2006). With no citizenship rights, Blacks were socially and politically isolated from participating in society with the exception of serving in subservient roles for Whites. The passage of the Fourteenth Amendment in 1865 mandated states to recognize all residents as citizens and protect their US constitutional rights. Although this legislation was significant, Blacks still did not own the necessary resources (e.g. land and assets) to fully integrate into mainstream US society. Blacks were regulated to substandard housing conditions both in rural and urban areas throughout the US (DuBois, 1996). Throughout the Reconstruction period (1865-1877), Blacks remained segregated from Whites, particularly in the South, because Whites still controlled a wealth of the economic, educational, and political resources (Hine et al., 2006).

Throughout the late nineteenth century through the midtwentieth century, several factors contributed to the social isolation of Blacks in the US (Hine et al., 2006). The continued disenfranchisement of Blacks, the practice of Jim Crow laws in the South, and lynching of Blacks in the South among other factors ensured Blacks did not have equal opportunities for life, liberty, and pursuit of happiness. The milestone Plessy v. Ferguson (1896) ruling reinforced the legality of racial segregation between Blacks and Whites and established the 'separate but equal' standard. The judicial support for segregation further isolated Blacks from living a quality of life compared to Whites. Over fifty years later, the passage of Brown v. Board of Education of Topeka (1954) overturned legalized segregation in educational institutions. Additionally, the efforts of the Civil Rights movement led to passage of historic legislations such as the Civil Rights Act of 1964, which outlawed discrimination against people of color and women in public facilities. Other significant accomplishments associated with the Civil Rights Movement included the Voting Rights Act of 1965, Executive Order 11246 by President Lyndon B. Johnson, and the Civil Rights Act of 1968 to name a few (Hine et al., 2006). In spite of these monumental legislations, Blacks in the post-Civil Rights era US continued to face structural inequalities related to racially discriminatory beliefs and practices.

\section{Personal Troubles}

Black athletes have a long history of experiences with racial discrimination and social isolation at PWIs (Adler \& Adler, 1991; AIR, 1988, 1989; Anshel, 1990; Benson, 2000; Hawkins, 1999; Lawrence, 2005; Sailes, 1993; Singer, 2005). Since the late nineteenth century, Black athletes have been marginalized at PWIs. Famous Black athletes during this era such as Paul Robeson (Rutgers University; football), William Henry Lewis (Amherst College; football), and W.T.S. Jackson (Amherst College; football) all have documented experiences with social isolation as racial minorities in their classes as well as on their athletic teams (Wiggins, 1991). The negative stereotypes Black athletes faced at PWIs stemmed from the pervasiveness of the dumb jock myth (Edwards, 1984; Harrison \& Lawrence, 2004; Hawkins, 2010; Sailes, 2010; Smith, 2009). The basis of this theory suggests Black males are innately athletically superior, yet intellectually inferior (Azzarito, Burden, \& Harrison, 2004; Edwards, 1984; Harrison, 2001; Hunt, Ivery, \& Sailes, 2010; Martin, Harrison, Stone, \& Lawrence, 2010; Sailes, 2010). Despite the fact that the dumb jock theory has yet to be supported by scientific research, the insidious acceptance of this theory within US educational institutions has presented significant psychological and social obstacles for Black athletes (Edwards, 1984; Sailes, 2010; Singer, 2008). The prevalence of these racist stereotypes within discursive practices at US educational institutions has contributed to negative academic outcomes, limited personal development, and poor psychological adjustments for Black athletes (Benson, 2000; Comeaux \& Harrison, 2007; Harrison \& Lawrence, 2004; Singer, 2008). Thus, these Black athletes were victims of stereotype threat (Steele \& Aronson, 1995). Stereotype threat refers to the fact that Black athletes at PWIs academically underperform due to the presence of increased psychological pressure (both consciously and subconsciously) to disconfirm the negative stereotypes associated with their academic capabilities.

\section{Intersection \#2: Academic Neglect}

The second common theme present in both the literature on Blacks in the US as well as Black athletes at PWIs is the shared experience with academic neglect. Education has been considered the gateway to achieving the American Dream of economic stability and overall quality of life. However, the acceptance of racist beliefs that subordinate Blacks has created significant barriers for Blacks to attain levels of education at rates comparable to Whites (ETS, 2011).This next section outlines the history of academic neglect against Blacks in the US educational system in connection with the contemporary academic neglect experienced by Black athletes at PWIs.

\section{Public Issue}

Historically, educational opportunities for Blacks in the US have been significantly limited and often times non-existent (Gutek, 1986; Hawkins, 2010; Henderson \& Kritsonis, 2007; Hikes, 2005; Palmer \& Gasman, 2008; Roebuck \& Murty, 1993). For example, prior to the Civil War only 28 Blacks graduated from college (Willie, Grady, \& Hope, 1991). Although Blacks in the north had more opportunities to earn an education, de jure (legalized) racism remained a major obstacle for Blacks in their quest to acquire traditional forms of education (Hikes, 2005). In response to this de jure racism, Blacks were forced to establish their own educational institutions (e.g. African Methodist Episcopal (AME)), along with the assistance of a handful of White organizations such as the Quakers, Presbyterians, American Missionary Association (AMA), Christian Methodist Episcopal (CME), the Bureau of Refugees, Freedmen's societies, and Abandoned Lands (Gallien \& Peterson, 2005; Hawkins, 2010; Walther, 1994). The first Black colleges were established in the north (Cheyney in 1837; Lincoln in 1854; Wilberforce in 1856) by Christian missionaries (Branson, 1978; Fleming, 1984).

Following the Emancipation Proclamation of 1865, which legally ended the practice of slavery in the US, the US government initiated widespread efforts to establish educational facili- 
ties for Blacks (Browning \& Williams, 1978; Fleming, 1984). Many leaders in the South remained ambivalent towards granting equal educational opportunities to Blacks (Fleming, 1984). In concert with these racist attitudes, several states passed laws that alienated Blacks and restricted their educational opportunities to vocational training (Browning \& Williams, 1978). The racist laws also known as Black codes were established to ensure Blacks remained subservient labor for Whites (Hine et al., 2006). In 1890, the monumental Morrill Land Grant Act was passed and all states were required to either provide separate schools for Blacks or integrate Blacks into existing institutions. As a result, 16 Black colleges were established to provide opportunities Blacks in vocational areas such as mechanical arts and agricultural sciences (Fleming, 1984). Although these educational gains were a sign of progress, these separate and unequal institutions reinforced the prevailing ideology of White intellectual superiority (Fleming, 1984; Hikes, 2005; Schwaneger, 1969; Wilson, 1994).

Over a century has passed since Brown v. Board of Education of Topeka (1954) and many Blacks still attend largely segregated and unequal primary and secondary schools. A recent study revealed that $39 \%$ of Black students attend an intensely segregated school (90 to 100\% racial minority) (ETS, 2011; Orfield, 2009). Accompanying the racial segregation is the lack of qualified teachers. A recent study by Aud, Fox, and KewalRamani (2010) found that in predominantly Black high schools, $25 \%$ of the math teachers did not possess a college major or a standard certification in the main subject they taught. In comparison, predominantly White high schools, $8 \%$ of the math teachers did not have a college major or a standard certification in the main subject they taught. These disparaging statistics support the notion of academic neglect of Blacks in the US primary and secondary educational systems.

\section{Personal Troubles}

Often times Black males are marginalized by the educational system through dominant discourses on intelligence, smartness, and academic achievement (Hatt, 2007). Dominant discourses are present in institutional (e.g. culturally bias standardized tests) and cultural practices (e.g. the dearth of African and African American literature courses offered at the primary and secondary level) (Hawkins, 2010). Many Black students as early as preschool begin to be tracked into remedial or special education classes (Hatt, 2007; McBay, 1992; Wright-Edelman, 1988). Consequently, this academic stigmatizing contributes to Black students' low academic achievement, low self-efficacy, and increased likelihood of attrition (Hatt, 2007).

More specifically at the post-secondary level, Black athletes must cope with the label of being dumb jocks (Edwards, 1984; Harrison \& Lawrence, 2004; Hawkins, 2010; Sailes, 2010; Smith, 2009). The acceptance of this insidious stereotype has been reinforced by previous research findings that Black athletes who participated in revenue producing sports were more likely to enter college academically underprepared (AIR, 1989; Purdy, Eitzen, \& Hufnagel, 1985; Sellers, 1992; Shulman \& Bowen, 2001) and less likely to achieve academic success compared to their college student peers (Ervin, Saunders, Gillis, \& Hogrebe, 1985; Gaston-Gayles, 2005; Purdy et al., 1985; Shulman \& Bowen, 2001). Thus, reinforcing the notion that Black males innately possess athletic talents, but intellectually they are limited (Edwards, 1994; Hawkins, 2010; Lapchick,
1991; Sailes, 2010; Sellers, 2000).

Conversely, several scholars have argued the academic performance of Black athletes' is less reflective of their individual merits, but more indicative of institutional arrangements and educational malpractice which treat them as intellectually inferior (Adler \& Adler, 1991; AIR, 1988, 1989; Benson, 2000; Gaston-Gayles, 2005; Hawkins, 1999; Sellers, 1992). A few widely publicized cases of institutional neglect in regards to Black male student athletes were the cases of Kevin Ross, Dexter Manley, and Gregg Taylor (Donnor, 2005; Ferris, Finster, \& McDonald, 2004; Johnson, 1985; Sellers, 2000). Each of these athletes enrolled in their respective institutions with severe academic learning disabilities. Ross was functionally illiterate after spending four years at Creighton University (Sellers, 2000). Similarly, Manley was also functionally illiterate after three years at Oklahoma State University before entering the National Football League (NFL) draft (Ferris et al., 2004). Taylor had his athletic scholarship terminated after refusing to participate in the team's practices because he felt it impeded his academic progress (Johnson, 1985). Although these Black athletes were confronted with severe learning disabilities, they share a similar experience with many Black athletes who are primarily admitted to generate revenue from their athletic abilities (Edwards, 1984, 2000; Funk, 1991; Hawkins, 2010; Sailes, 2010; Singer, 2008; Smith, 2009). Instead of providing, the adequate academic support necessary for them to develop academically these institutions primarily focused on exploiting them for their athletic abilities. These isolated cases were supported by the previous studies that suggested the academic neglect of Black male student athletes remains a major problem at many PWIs (Adler \& Adler, 1991; AIR, 1988, 1989; Benson, 2000; Gaston-Gayles, 2005; Hawkins, 1999; Sellers, 1992).

\section{Intersection \#3: Economic Deprivation}

Another common experience shared between both Blacks in the broader US society and Black athletes at PWIs is the experience with economic deprivation, disadvantage, and exploitation. The economic exploitation of Black athletes at major Division I institutions resembles the historical exploitation of Blacks in the broader US society. Although the conditions under which the exploitation transpired were vastly different, the stratification of power, inequitable distribution of wealth and resources, and disparate outcomes are eerily similar. In order for Blacks to attain true equality, structural policies and practices must take into account historical inequalities within the US society, and thus be sufficiently reformed to provide fair treatment of all individuals regardless of race (DuBois, 1996; Mills, 1959).

\section{Public Issue}

US capitalism operates under a class stratification system whereby three distinct classes (capitalist, middle, and working) fulfill specific economic roles (Sage, 1998). The capitalist class is typically small in number (roughly 2 percent), yet represents the wealthiest Americans who control the means of production (e.g. capital and land). The middle class consist of a group of income earners who share some power with capitalists, but remain largely dependent on the capitalist class who owns a majority of resources (e.g. wealth, assets, etc.). The working 
class is the lowest class with no ownership and limited economic resources. In the US, these stratifications were established along class, gender, and racial identification. Throughout history, Whites have dominated the capitalist and middle classes whereas Blacks were predominantly members of the working class. As members of the working class, Blacks experienced various forms of oppression, discrimination, and economic deprivation (Sage, 1998).

Since the inception of slavery in 1619, Blacks were a source of labor for the economic profitability of Whites. Following the Emancipation Proclamation in 1865, Blacks continued to struggle with gaining economic independence because Whites retained control over the regulation of wages and prices, land, and property (Hine et al., 2006). Throughout the twentieth century, Blacks continued to experience economic deprivation. In 1959, Blacks constituted 25.1\% of Americans living under the poverty line (US Bureau of the Census, 1982). Between 1979 and 1980, the number of Blacks in poverty increased from 2.5 million to 19.7 million compared to the number of Whites in poverty 530,000 to 8.6 million. In spite of the fact that Blacks only constituted $12 \%$ of the US population, they made up over $29 \%$ of the poverty population. More specifically, in 1980 , the poverty rate for Blacks (32\%) was over three times the rate of Whites (10\%). These statistics highlight the level of economic deprivation experienced by Blacks throughout the mid-twentieth century (US Bureau of the Census, 1982). Poverty among Blacks is an intergenerational process perpetuated by structural inequalities and class stratification (Bell, 1992). In 1988-1989, Black children attended schools where over one-third (43\%) of their classmates lived in poverty (Orfield, 2009). In 2006-2007, Black children attended schools where $59 \%$ of their classmates lived in poverty compared to White students who attended schools where $32 \%$ of their classmates lived in poverty. Children who grow up in poverty are more likely experience substandard educational opportunities, poor health and nutrition outcomes, residential insecurity, and exposure crime and gang activity. Poverty levels are the number one indicator of economic deprivation. Blacks' longstanding experience with poverty perpetuates the lack of economic opportunities and limits access to upward social mobility (Orfield, 2009).

Unemployment and annual income are additional indicators of economic deprivation (US Department of Commerce, 1993). In 1979, the Black unemployment rate was almost twice that of Whites. Ten years later in 1989, the Black unemployment rate increased to over twice the rate of Whites, $13 \%$ and $5 \%$, respectively. Given that Blacks were a racial minority (roughly 12 percent) of the overall US population, yet constituted a larger percentage of those in poverty highlights the structural racism embedded in US society. Moreover, Blacks earned less income than Whites did over a 23-year span. From 1984 to 2007, the wealth gap between Blacks and Whites increased from $\$ 20,000$ to $\$ 95,000$. Moreover, according to the most recent census data, the household income for Blacks and Whites was \$32,303 and \$49,471, respectively (DeNavas-Walt et al., 2011). Considering wealth and income are the strong indicators of economic stability, Blacks remained significantly disadvantaged compared to Whites (Shapiro, Meschede, \& Sullivan, 2010).

\section{Personal Troubles}

Several critics of the NCAA purported the structure of major
Division I intercollegiate athletics was inherently exploitive of student athletes, particularly Black athletes (Barbalias, 2004; Byers, 1995; Edwards, 1984; Hawkins, 2010; Lapchick, 1984; Sack \& Staurowsky, 1998; Smith, 2009; Zimbalist, 2001). For years, Black athletes have been overrepresented in the two largest revenue-generating sports, football, and men's basketball, while simultaneously graduating at lower rates than their student athlete counterparts have. In 2007-2008, Black males represented 25\% of all student athletes in Division I, $60.4 \%$ of Division men's basketball players and $46.4 \%$ of Black football players (NCAA, 2009). In 2008, there were 821,481 Black males enrolled in post-secondary instiutions which was roughly $5 \%$ of all undergraduate enrollment and $36.2 \%$ of Black student enrollment (NCES, 2009). As a result, several scholars have suggested Black athletes were being exploited by these institutions for financial gain (Edwards, 1985; Hawkins, 1999, 2010; Rhoden, 1989; Sellers, 2000; Singer, 2005; Smith, 2009).

Polite (2011) defines exploitation as "the unfair treatment or use of, or the practice of taking selfish or unfair advantage of, a person or situation, usually for personal gain” (p. 2). Under this definition, the NCAA and its member institutions exploit Black athletes, as well as other non-Black athletes in participating in the top two revenue-generating sports, for revenue generation without adequately compensating them for their services (Byers, 1995; Funk, 1991; Hawkins, 2010; Smith 2009; Zimbalist, 2001). The relationship between the NCAA, member institutions, and student athletes in revenue generating sports (e.g. FBS football and Division I men's basketball) is problematic on multiple levels. One, the educational missions of these institutions promotes academic excellence and personal development of its students. If Black athletes are being recruited to generate revenue for their athletic abilities, then their primary purpose is not to receive a paramount educational experience rather it is to excel athletically to generate revenue for the athletic departments, the institution, and other institutional stakeholders (e.g. NCAA staff, Conference Commissioners, Head Coaches, etc.) (NCAA, 2011a). Two, these student athletes in revenue generating sports are generating millions of dollars for their institutions and not receiving even a fraction of compensation for their contributions. This is not only ethically wrong, but also maybe in violation of anti-trust laws enacted by Sherman Anti-Trust Act (Acain, 1998; Davis, 1999). Therefore, the practice of athletic exploitation reveals the overemphasis of athletics over academics at a several US post-secondary institutions presents significant problems that are reflective of the broader social issue of economic exploitation of marginalized groups (Funk, 1991; Hawkins, 2010; Lapchick, 1984; Sack \& Staurowsky, 1998; Smith, 2009; Wolff \& Keteyian, 1990).

In 2011, the NCAA reported $\$ 845.9$ million in revenue, an overwhelming amount of revenues was generated from a rights agreement with Turner/CBS Sports for coverage rights of the March Madness Men's Basketball Tournament (NCAA, 2012). Although the revenue generated on "the backs of our Black brothers" continues to increase at exponential rates, the low graduation and high attrition rates of Black athletes remained a major problem at NCAA member institutions who notably promoted the prioritization of academic excellence in their mission statements (Hawkins, 2010: p. 94). Conversely, findings from a recent NCAA study revealed the most recent graduation rates for Division I African American male student athletes was $62 \%$ which was 21 percentage points lower than the graduation rate of their White male student athlete counter- 
parts (NCAA, 2011c). Although proponents of the NCAA proclaim these student athletes are receiving a paramount educational experience, these statistics suggest otherwise (NCAA, 2011a: p. 1). The inverse relationship between the money generated in sports, where Black males were overrepresented, and low graduation rates of these same students suggests these athletes were being exploited for their athletic labor. Consequently, the overemphasis on athletic performance contributes devaluation of their holistic development (Edwards, 1973a, 1973b, 1984, 1994; Hawkins, 2010; Polite \& Hawkins, 2011; Sellers, 2000; Smith, 2009).

\section{Intersection \#4: Limited Leadership Opportunities}

Throughout history, Blacks have been overlooked and underrepresented in various leadership roles. Similar to Blacks in the broader US, Black male student athletes experienced a lack of leadership opportunities largely based on racial stereotypes about their intellectual abilities (Steele \& Aronson, 1995). These stereotypes are deeply rooted in US institutional practices (Sage, 1998). In concert with Mills' (1959) sociological imagination, the history of Black exclusion from leadership opportunities in US society along with the lack of leadership opportunities afforded to Black athletes during as well as following their athletic careers is inextricably linked. In order to address this prevailing public issue, it is imperative to understand its origins from a socio-historical context. Once this understanding is attained, then efforts to deconstruct and rearrange current structural arrangements can occur and widespread empowerment among the oppressed can manifest (Hawkins, 2010; McDonald \& Birrell, 1998; Spencer, 2010).

\section{Public Issue}

Prior to the Reconstruction period (1865-1877), Blacks did not possess any citizenship rights and therefore unable to pursue leadership opportunities (Hine et al., 2006). An example of Black exclusion from leadership was evident in the lack of Black representation in the US military from the later nineteenth century through the early twentieth century. Although Blacks were allowed in the military after 1865, they were restricted to strictly subordinate roles. In 1917, there were over 5000 Blacks in the Navy, but nearly all of them were relegated to subservient roles such as waiters and kitchen attendants. In the Army, Blacks were also limited to serving as road construction workers, cooks, and bakers. During World War I, only 42,000 out of the over 380,000 Black males in the military were allowed to serve in combat. This practice was supported by fallacious studies that promoted the ideology of White supremacy. In 1925, a study conducted by the American War College reported that Blacks were physically unfit for combat, mentally incompetent, and innately inferior to Whites. Negative propaganda such as this aforementioned study influenced a majority of White military leaders, politicians, and journalists to perceive Black soldiers as inferior (Hine et al., 2006).

During the Reconstruction era, most Black males feared pursuing political offices for fear of retaliation from Southern Whites. In spite of these threats, Blacks experienced marginal progress in terms of political representation during the late nineteenth century. Between 1865 and 1877, 14 Black males served in the US House of Representatives. In response to
Black progress in US politics, Whites employed several deceitful tactics to disenfranchise Blacks from voting such as the use of literary tests, poll taxes, and property qualifications. Thus, the progress made during the late 1800s was stifled by the turn of the century. In 1900, nearly all congressional representatives were White. The Fifteenth Amendment, which granted Blacks voting rights, was passed in 1869, but the aforementioned barriers limited Black participation. In 1965, the President Lyndon B. Johnson passed the Voting Rights Act, which prohibited educational requirements as qualification for voting. The passage of this law meant that Blacks could not be denied their civil right to vote based on educational attainment (Hine et al., 2006)

Political offices epitomize leadership roles in US society. Local, state, and national politicians have the ability to create laws, which govern the lives of all Americans. Throughout the mid-twentieth to early twenty-first century, Blacks continued to make strides in political representation, but remained largely underrepresented in Congress. For example, from 1969-1971, out of the 535 members of Congress there were less than 10 Black members (Amer, 2008). At the turn of the century, from 1999-2001, the number has remained between 39 and 43. Currently, African Americans account for $8.1 \%$ of the members of the $112^{\text {th }}$ US Congress, which is slightly lower than the $12.6 \%$ African Americans among the total US population (Manning, 2011; US Bureau of Census, 2012). Despite progress such as the election of the first African American president, President Barack Obama, the persistent underrepresentation of Blacks in the US Congress signifies the lack of leadership opportunities available to Blacks in the nation's higher leadership positions.

\section{Personal Troubles}

A longstanding problem facing the NCAA and its member institutions has been the persistence underrepresentation of racial/ethnic minorities in leadership positions (Woods, 2011). Since the mid-twentieth century, Blacks have had a strong presence as participants in intercollegiate football, men's basketball, track and field, and women's basketball. Yet, conspicuously Blacks have been underrepresented in the leadership positions of these sports at the intercollegiate level. According to a study conducted by Harrison (2004), in 2003, Blacks made up nearly $50 \%$ of Division IA football players, but less than $1 \%$ of these schools had Black football head coaches. From 1996 to 2004, only one Black head coach had been hired as of 2004 only 21 Black males had held head coaching positions in Division IA football. These stark discrepancies between player representation and the lack of head coach representation suggests Blacks are viewed as athletic commodities, but not considered fit for head coaching positions (Brooks \& Althouse, 2000).

More recently, Lapchick, Hoff, \& Kaiser (2011) found that only $11.7 \%$ of the Football Bowl Subdivision (FBS) schools' athletics directors were people of color. The 2011 season started with 15\% (18 out of 120) FBS head football coaches were Black. As of March 25, 2011, at the highest levels of the NCAA headquarters (EVP (Executive Vice President)/SVP (Senior Vice President)/VP (Vice President)) Blacks made up $25 \%$ compared to $75 \%$ for Whites. In addition, $100 \%$ of the 11 FBS conference commissioners were White males. In all of Division I, excluding HBCU conferences, all 30 (100\%) of Division I conference commissioners were White. The underrepresentation of Blacks in all levels of intercollegiate athletics 
suggests race and racism remain significant mitigating factors in leadership opportunities available to Blacks (Lapchick et al., 2011).

A possible explanation for the lack of Black representation in leadership positions in sport is the continued practice of racial stacking. Racial stacking is "the disproportional relegation of athletes to specific sport positions on the basis of the prescribed characteristic of race” (Leonard, 1987: p. 403). Racial stacking is viewed as discriminatory because players are assigned certain positions based on racial stereotypes and not only actual ability (Anderson, 1993; Best, 1987; Chu \& Segrave, 1981; Curtis \& Loy, 1978a, 1978b; Eitzen \& David, 1975; Eitzen \& Tessendorf, 1978; Massengale \& Farrington, 1977; Medoff, 1977; Sailes, 2010). Singer (2005) found that African American male football student athletes at Division I PWIs felt they were not afforded leadership and major decision-making opportunities in college or professional sports due to their race. The participants' experience with racial stacking negatively affected their perceptions of leadership opportunities available to them in sports. The underrepresentation of Blacks in sport leadership positions along with the concurrent prevalence of racial stacking reinforces the dominant race logic of White supremacy that has plagued both Blacks in sports and Blacks in the broader US society.

\section{Discussion}

Using a sociological imagination for the critical examination of Black athletes' experiences at PWIs provides insight into how these institutions can shift from simply operating as "modes of integration" merely reinforcing structural inequalities to "modes of historical change" that create true equality of opportunity for all individuals in the US (Mills, 1959: p. 47). History informs us that when societies (e.g. US) or organizations (e.g. NCAA), reach certain point of imbalance social movements or revolutions are inevitable. The aforementioned personal troubles and public issues accompanied by public distrust of the growing commercialization of major college sports should serve as notice to the NCAA that a revolution is mounting unless major structural reforms take place.

The NCAA's ideological stance operates under what Mills' (1959) described as a Grand Theory approach. The Grand Theory involves the establishment of social norms and social regularities within a social system to maintain social equilibrium. This social equilibrium is maintained in two ways, through socialization and social control. The NCAA's ideological stance is rooted in the principle of amateurism whereby student athletes participate in intercollegiate athletics primarily for intrinsic purposes as an extension of the educational experience. The key idea is that these student athletes are not being viewed as institutional employees and thus should not be compensated fully for their revenue generation. From the beginning of the recruiting process, Black athletes are groomed to view themselves as amateurs and thus view any behavior outside the confines of the NCAA bylaws as deviant. Social control is established through harsh punishments to violators (e.g. Reggie Bush (USC; football), Cameron Newton (Auburn; football), and Terrelle Pryor (Ohio State; football). The NCAA's use of a Grand Theory approach ensures the dominant power structure remains intact and those who are being exploited remained limited in their ability to alter the current structure (Mills, 1959).
The psychological benefit of the Grand Theory lies in the fact that its standards become the basis for adherence to the power structure as well as for opposition to it (Mills, 1959). Previous theorists have described "social norms as 'legitimations' (Max Weber), 'collective representation' (Emil Durkheim), 'dominant ideas' (Karl Marx), and 'public sentiments' (Herbert Spencer)” (Mills, 1959: p. 36). The core issue associated with these analyses is the possession and exertion of power. Although the Grand Theory suggests social equilibrium benefits all actors, often times the main benefactors of social equilibrium are the individuals in power. In the case of intercollegiate athletics, the NCAA bylaws serve as the social norms that retain social control over student athletes, but the individuals who benefit most from the multi-billion dollar college sport industry are the NCAA administrators, Bowl Championship Series (BCS) organizers, Conference Commissioners, Head Coaches, and the institutions and their athletic departments. The individuals who benefit the least from the system are the student athletes who fuel the system (Byers, 1995; Hawkins, 2010; Sellers, 2000; Smith, 2009; Zimbalist, 2001).

Moreover, liberalism is deeply rooted in the US political and social values (Mills, 1959). In regards to social sciences, liberal practicality has been applied in the examination of various social problems. Liberal practicality is the belief that a balance must be retained through the small individual reform efforts. For example, under liberal practicality, issues facing Blacks in the US such as poverty, mortality rates, health disparities, and academic achievement gap should be addressed separately. Inherent in the liberal practicality approach is the idea that social problems are scattered and thus must be addressed in a sequential fashion. The pluralist causation of these problems requires "piecemeal reform", but fails to take into account the interconnectedness of social problems that are created by social structures (Mills, 1959: p. 85). The sociological imagination provides an opportunity to show how social problems are interconnected to a socio-historical lineage and therefore must be addressed concurrently rather than separately. In other words, the personal troubles facing Black athletes at PWIs are not separate from the public issues facing Blacks in the broader US, thus both personal troubles and public issues must be addressed simultaneously since their inextricably linked (Mills, 1959).

\section{Implications}

A recommendation for addressing the personal trouble and public issue of racial discrimination/social at PWIs is to implement effective strategies that fully integrate Black athletes into the student body. Many PWIs have diversity or multicultural offices that are designed to recruit racial/ethnic minority students and provide them with a support system that will enable them to have a positive college experiences and ultimately graduate. These programs should be integrated with the athletic departments to establish effective programs and services to assist this unique group of students. Another recommendation for integrating Black male student athletes into the general study body is to combine student athlete academic services with institutional student academic services for the student body. This integration would not require a total overhaul of successful student athlete academic support services, but merely strengthening the partnerships between the two so they do not operate in complete autonomy. The implementation of these recommendations could assist major FBS institutions in improving 
academic and social experiences of Black athletes.

A major reform measure that should be implemented immediately is the establishment and enhancement of partnerships between NCAA, member institutions, and the K-12 US public educational systems particularly those low resource schools to improve academic preparation prior to college enrollment (Edwards, 2000; Funk, 1991; Shropshire, 1997). Previous studies have revealed that a significant number of Black male student athletes particularly in the major revenue generating sports come from low-income communities and low resource schools which can impact their academic preparedness (AIR, 1988, 1989; Purdy et al., 1985; Sellers, 1992; Shulman \& Bowen, 2001). These partnerships could address the issue of academic preparedness at earlier stages in a student athletes' life and thus enhance their chances of excelling academically in college (Edwards, 2000). In addition, these partnerships would send the message that these institutions are truly concerned with addressing the academic achievement gap and not simply interested in exploiting these Black athletes for their athletic abilities (Edwards, 2000; Hawkins, 2010; Smith, 2009).

The NCAA and its member institutions should also consider collaborating with other private and public organizations that promote Black academic achievement. For example, the NCAA could collaborate with organizations such as the Journal for Blacks in Higher Education (JBHE), the National Children's Defense Fund, the National Association for the Advancement of Colored People (NAACP), and the Science, Technology, Engineering, and Mathematics (STEM) Education Coalition among other similar organizations. These partnerships could focus on identifying and disseminating best practices for eliminating the current academic achievement gap as well as recognize schools that demonstrate significant improvement from year to year in eliminating the academic achievement gap among Black and White athletes. Similar to the annual TIDES reports, this alliance could create a national ranking of institutions that graduate Black male student athletes at high rates as well as institutions that show improvement from year to year and specifically highlight the programs they have implemented to accomplish this improvement. This partnership would optimize efforts directed at improving academic achievement and experiences of Black male student athletes at PWIs.

A recommendation to address the economic deprivation of Black athletes at PWIs is to eliminate the myth of amateurism principle as it is currently applied to FBS football and Division I men's basketball student athletes. Student athletes are already compensated in the form of scholarships; therefore, they should not be viewed as amateurs (Byers, 1995; Funk, 1991; Sack \& Staurowsky, 1998; Zimbalist, 2001). This outdated label of amateurism denies student athletes of their fundamental right to fair compensation for their services and further supports the notion that the NCAA is serving as exploitive cartel of student athlete labor. One feasible option is to redistribute the profits generated through a commercial/education model through a revenue sharing plan that fairly compensates student athletes as well as place a higher emphasis on educational values (Acain, 1998). This revenue sharing plan is not an all-inclusive solution to the problem of economic exploitation in major intercollegiate athletics, but it represents a step in the direction of minimizing the exploitation of student athletes as well as avoiding any violation of current anti-trust lawsuits enacted by the Sherman
Anti-Trust laws (Acain, 1998).

Recommendations for increasing leadership opportunities for Black males in intercollegiate athletics must also incorporate structural reform efforts. In 2003, the Black Coaches Association (BCA) funded the hiring report card project to serve as a watchdog on the hiring practices of NCAA Division I football programs (Keith, 2011). The Fritz Pollard Alliance (FPA) led by John Wooten advocated the hiring and promotion of minority candidates with both the NFL and NCAA. Increasing awareness of the hiring disparities is a key part of addressing the underrepresentation of Black leadership in intercollegiate athletics. The NCAA's Diversity and Inclusion Office published a Best Practices report outlining key recommendations for improving overall diversity among athletic departments. One list in the report outlines effective hiring practices such as implementing strategies that attract diverse candidates in the hiring process, provide job announcements to historically diverse colleges, and utilize grants or internships to hire racial/ ethnic minorities and women (NCAA, 2011b). College presidents, athletic directors, conference commissioners, coaches, faculty, and athletes must be committed to improving the problem in order for true change to take place (Brooks \& Althouse, 2000). Noteworthy programs offered by this office include the football professional development programs, Fellows Leadership Development Programs, NCAA Postgraduate Internship Program, Ethnic Minority Enhancement Postgraduate Scholarship for Careers in Athletics, and Diversity Education (Diversity Training Workshops) (NCAA, 2011b).

\section{Conclusion}

This paper provides a socio-historical context for examining the relationship between the personal troubles of Black athletes at PWIs and the public issues facing Blacks throughout US history. Institutional policies and practices aimed at improving academic experiences and achievement of Black athletes at PWIs must be "sociologically grounded and historically relevant” (Mills, 1959: p. 143). Meaningful efforts, whether in theory or practice, must target the structural arrangements in the broader US society that perpetuate existing inequalities. Dr. Harry Edwards, renowned sports sociologist and social justice advocate, professed this inextricable connection: "Black athletes' academic problems are in large part rooted in and intertwined with Black youths' societal circumstances more generally there can be no effective resolution of the educational circumstances of Black athletes at any academic level except in coordination with commensurate efforts in society" (Edwards, 2000: p. 10).

The NCAA and its member institutions have an opportunity to take a leadership role in addressing significant personal troubles of Black male student athletes as well as public issues of Blacks in the broader US The implementation and constant improvement of these recommendations could enhance current services and programs as well as serve as example for other social institutions (Sage, 1998). This paper is a call to action for structural changes within the current structure of intercollegiate athletics. If institutions of higher education are the beacon of leadership and intellectual advancement, then these institutions must be willing to implement radical structural reform efforts that change the status quo of intercollegiate athletics. Only 
when the NCAA and its member institutions take bold steps will it live up to its mission to "govern competition in a fair, safe, equitable and sportsmanlike manner, and to integrate intercollegiate athletics into higher education so that the educational experience of the student athlete is paramount" (NCAA, 2011a: p. 1).

\section{Acknowledgements}

I would like to thank Dr. Billy Hawkins for his input and editorial assistance with this manuscript.

\section{REFERENCES}

Acain, M. P. (1998). Revenue sharing: A simple cure for the exploitation of college athletes. 18 Loyola of Los Angeles Entertainment Law Review, 307.

Adler, P. A., \& Adler, P. (1991). Backboards and blackboards: College athletics and role engulfment. New York: Colombia University Press.

AIR (1988). Summary results from the 1987-1988 national study of intercollegiate athletics. Studies in Intercollegiate Athletics. Palo Alto, CA: Center for the Study of Athletics.

AIR (1989). The experiences of Black intercollegiate athletes at NCAA division I institutions. Studies in Intercollegiate Athletics. Palo Alto, CA: Center for the Studies of Athletics.

Amer, M. L. (2008). African American members of the United States congress: 1870-2008. CRS Report for Congress, 1-67. URL (last checked 17 February 2012)

http://www.senate.gov/reference/resources/pdf/RL30378.pdf

Anderson, D. (1993). Cultural diversity on campus: A look at intercollegiate football coaches. Journal of Sport and Social Issues, 17, 6166. doi:10.1177/019372359301700108

Anshel, M. H. (1990). Perceptions of Black intercollegiate football players: Implications for the sport psychology consultant. Sport Psychologist, 4, 235-248.

Azzarito, L., Burden, Jr., J., \& Harrison Jr., L. (2004). Perceptions of athletic superiority: A view from the other side. Race, Ethnicity, and Education, 7, 149-166. doi:10.1080/1361332042000234277

Barbalias, P. (2004). Black student-athletes: Improving their collegiate experience. URL (last checked on 17 February 2012).

http://www.uvm.edu/ vtconn/v17/barbalias.html

Bell, D. A. (1992). Faces at the bottom of the well: The permanence of racism. New York: Basic Books.

Benson, K. (2000). Constructing academic inadequacy: African American athletes' stories of schooling. The Journal of Higher Education, 71, 223-246. doi:10.2307/2649249

Best, C. (1987). Experience and career length in professional football: The effect of positional segregation. Sociology of Sport Journal, 4, 410-420.

Branson, H. R. (1978). Black colleges of the North. In C. V. Willie, \& R. R. Edmonds (Eds.), Black colleges in America. New York: Teachers College Press.

Brooks, D., \& Althouse, R. (2000). African American head coaches and administrators: Progress but...? In D. A. Brooks, \& R. Althouse (Eds.), Racism in college athletics: The African American athlete's experience (2nd ed., pp. 85-118). Morgantown, WV: Fitness Information Technology.

Browning, J., \& Williams, J. (1978). History and goals of Black institutions of higher learning. In C. V. Willie, \& R. R. Edmonds (Eds.), Black colleges in America. New York: Teachers College Press.

Byers, W. (1995). Unsportsmanlike conduct: Exploiting college athletes. Ann Arbor, MI: The University of Michigan Press.

Chu, D. B., \& Segrave, J. O. (1981). Leadership and ethnic stratification in basketball. Journal of Sport and Social Issues, 5, 15-32. doi:10.1177/019372358100500102

Coakley, J. (2009). Sports in society: Issues and controversies (10th ed.). New York, NY: McGraw-Hill.
Comeaux, E., \& Harrison, C. K. (2007). Faculty and male studentathletes: Racial differences in the environmental predictors of academic achievement. Race, Ethnicity, and Education, 10, 199-214. doi:10.1080/13613320701330726

Comstock, A. P. (1912). Chicago housing conditions, VI: The problem of the negro. American Journal of Sociology, 18, 241. doi:10.1086/212075

Crouse, J., \& Trusheim, D. (1988). A case against the SAT. Chicago, IL: University of Chicago Press.

Curtis, J. E., \& Loy, J. W. (1978a). Positional segreation in professional baseball: Replication, trend data and critical observation. International Review of Sport Sociology, 4, 5-21. doi:10.1177/101269027801300401

Curtis, J. E., \& Loy, J. W. (1978b). Race/ethnicity and relative centrality of playing positions in team sports. Exercise and Sport Science Review, 6, 285-313. doi:10.1249/00003677-197800060-00008

Dandaneau, S. P. (2000). Taking it big: Developing sociological consciousness in postmodern times. Thousand Oaks, CA: Pine Forge Press.

Davis, T. (1999). Intercollegiate athletics in the next millenium: A framework for evaluating reform proposals. Marquette Law Review, 9, 253-271.

DeNavas-Walt, C., Proctor, B. D., \& Smith, J. C. (2011). Income, poverty, and health insurance coverage in the United States: 2010. In U. S. C. Bureau (Ed.), Washington, DC: US Government Printing Office.

Denzin, N. K. (1990). Presidential address on the sociological imagination revisted. The Sociological Quarterly, 31, 1-22. doi:10.1111/j.1533-8525.1990.tb00314.X

Denzin, N. K. (2001). Interpretive interactionism (Vol. 16). Thousand Oaks, CA: Sage.

Denzin, N. K., \& Lincoln, Y. S. (2005). The sage handbook of qualitative research (3rd ed.). Thousand Oaks, CA: Sage Publications.

Donnor, J. K. (2005). Towards an interest-convergence in the education of African-American football student-athletes in major college sports. Race, Ethnicity, and Education, 8, 48.

DuBois, W. E. (1996). The Philadelphia Negro: A social study (Reprint ed.). Philadelphia, PA: University of Pennsylvania Press.

Duderstadt, J. (2003). Intercollegiate athletics and the American university: A university president's perspective. Ann Arbor, MI: University of Michigan Press.

Edwards, H. (1973a). The Black athletes: 20th century gladiators for White America. Psychology Today, 7, 43-52.

Edwards, H. (1973b). Sociology of sport. Homewood, IL: Dorsey Press.

Edwards, H. (1980). The Struggle that must be: An Autobiography. New York, NY: Macmillan.

Edwards, H. (1984). The "Black dumb jock": An American sports tragedy. The College Board Review, 131, 8-13.

Edwards, H. (1985). Educating Black athletes. In D. Chu, J. U. Segrave, \& B. J. Becker (Eds), Sport and higher education (pp. 373-384), Champaign, IL: Human Kinetics.

Edwards, H. (1994). Playoffs and payoffs: The African American athlete as an institutional resource. Stanford, CA: Achieving Coaching Excellence.

Edwards, H. (2000). Crisis of Black athletes on the eve of the 21st century. Society, 37, 9-13. doi:10.1007/BF02686167

Eitzen, D. S., \& David, C. S. (1975). The segregation of Blacks by playing positions in football: Accident or design? Social Science Quarterly, 55, 948-959.

Eitzen, D. S., \& Tessendorf, I. (1978). Racial segregation by position in sports: The special case of basketball. Review of Sport \& Leisure, 3, 109-128.

Ervin, L., Saunders, S. A., Gillis, H. L., \& Hogrebe, M. C. (1985). Academic performance of student athletes in revenue generating sports. Journal of College Student Personnel, 26, 119-125.

ETS (2011). A strong start: Positioning young Black boys for educational success a statistical profile. In E. T. Service (Ed.), ETS's Addressing Achievement Gaps Symposium (pp. 1-5). Washington, DC: Educational Testing Service.

Ferris, E., Finster, M., \& McDonald, D. (2004). Academic fit for stu- 
dent-athletes: An analysis of NCAA division I-A graduation rates. Research in Higher Education, 45, 555-575. doi:10.1023/B:RIHE.0000040263.39209.84

Fleming, J. (1984). Blacks in college. San Francisco: Jossey-Bass Publishers.

Funk, G. D. (1991). Major violation: The unbalanced priorities in athletics and academics. Champaign, IL: Leisure Press.

Gallien, L. B., \& Peterson, M. S. (2005). Instructing and mentoring the African-American college student: Strategies for success in higher education. Upper Saddle River, NJ: Pearson Education, Inc.

Gaston-Gayles, J. L. (2005). The factor structure and reliability of the student athletes' motivation toward sports and academics questionnaire (SAMSAQ). Journal of College Student Development, 46, 317-327. doi:10.1353/csd.2005.0025

Gitlin, T. (2000). Afterword. The sociological imagination: 40th anniversity edition (pp. 229-242). New York: Oxford University Press.

Gutek, G. L. (1986). Education in the United States: A historical perspective. Englewood Cliffs, NJ: Prentice-Hall.

Harrison, C. K. (2004). "The score": A hiring report card for NCAA Division IA and IAA football head coaching positions. Orlando, FL: The Robeson Center and the Black Coaches Association (BCA).

Harrison, C. K., \& Lawrence, S. M. (2004). College students’ perceptions, myths, and stereotypes about African American athleticism: A qualitative investigation. Sport, Education \& Society, 9, 33-52. doi:10.1080/1357332042000175809

Harrison, L. Jr. (2001). Understanding the influence of stereotypes: Implications for the African American in sport and physical activity. Quest (00336297), 53, 97-114. doi:10.1080/00336297.2001.10491732

Hatt, B. (2007). Street smarts vs. book smarts: The figured world of smartness in the lives of marginalized, urban youth. The Urban Review, 39, 145-166. doi:10.1007/s11256-007-0047-9

Hawkins, B. (1999). Black student-athletes at predominantly White national collegiate athletic association (NCAA) division I Institutions and the pattern of oscillating migrant laborers. The Western Journal of Black Studies, 23, 1-9.

Hawkins, B. (2010). The new plantation: Black athletes, college sports, and predominantly White institutions. New York: Palgrave-MacMillan.

Helms, J. E. (1994). The conceptualization of racial identity and other "racial" constructs. In E. J. Trickett, R. J. Watts, \& D. Birman (Eds.), Human diversity: Perspectives on people in context (pp. 285-311). San Francisco, CA: Jossey-Bass.

Henderson, F. T., \& Kritsonis, W. A. (2007). Graduation rates at historically Black colleges and universities: A review of literature. $\mathrm{Na}$ tional Journal for Publishing and Mentoring Doctoral Student Research, 4, 1-11.

Hikes, Z. (2005). Maximizing student success: A coupled approach to student retention In J. L. B. Gallien, \& M. S. Peterson (Eds.), Instructing and mentoring the African American college student: Strategies for success in higher education (pp. 16-48). New York, NY: Pearson Education, Inc.

Hine, D. C., Hine, W. C., \& Harrold, S. (2006). The African-American odyssey: Since 1965 (3rd ed., Vol. 2). Upper Saddle River, NJ: Pearson Prentice Hall.

Hunt, T., Ivery, I., \& Sailes, G. (2010). Talented genetics or genetically talented: The historical rationale for Black athletic success. In G. Sailes (Ed.), Modern sport and the African American experience (pp. 137-154). San Diego, CA: Cognella.

Jencks, C., \& Phillips, M. (1998). The Black-White test score gap. Washington, DC: Brookings Institution.

Jensen, A. R. (1969). How much can we boost I.Q. and scholastic achievement? Harvard Educational Review, 33, 1-123.

Johnson, D. Q. (1985). Educating misguided student-athletes: An application of contract theory. Columbia Law Review, 85, 96-129. doi:10.2307/1122405

Jones, R. (1998). Proving Blacks inferior: The sociology of knowledge. In J. A. Ladner (Ed.), The death of White Sociology (pp. 114-135). Baltimore, MD: Black Classic Press.

Keith, F. A. (2011). A change has finally come. URL (last checked on 29 March 2012). http://www.bcasports.org/index.php?option=com_content\&view=arti cle\&id=74:february-10-2011\&catid=12:press-releases

Lapchick, R. (1984). Broken promises: Racism in American sports. New York: St. Martin's.

Lapchick, R. (1991). Five minutes to midnight: Race and sport in the 1990s. Lanham, MD: Madison Books.

Lapchick, R. (2006). Decisions from the top: Diversity among campus, conference leaders at Division IA institutions. URL (last checked 5 March 2012)

http://tidesport.org/Grad\%20Rates/2006_Demograhpic_release.pdf

Lapchick, R., Hoff, B., \& Kaiser, C. (2011). The 2010 racial and gender report card: College sport. URL (last checked 12 February 2012). http://tidesport.org/RGRC/2010/2010_College_RGRC_FINAL.pdf

Lawrence, S. M. (2005). Short communication: African American athletes' experiences of race in sport. International Review for the Sociology of Sport, 40, 99-110. doi:10.1177/1012690205052171

Lincoln, Y. S., \& Guba, E. G. (2000). Paradigmatic controversies, contradictions, and emerging confluences. In N. K. Denzin, \& Y. S. Lincoln (Eds.), The handbook of qualitative research (2nd ed., pp. 1065-1122), Thousand Oaks, CA: Sage Publications.

Manning, J. E. (2011). Membership of the 112th Congress. A profile. CRS Report for Congress: Prepared for Members and Committees of Congress (Vol. 7-5700, pp. 1-11), URL (last checked 12 February 2012).

http://www.senate.gov/reference/resources/pdf/R41647.pdf

Martin, B., Harrison, C. K., Stone, J., \& Lawrence, S. M. (2010). Athletic voices and academic victories: African American male student-Athlete experiences in the Pac Ten. Journal of Sport \& Social Issues, 34, 131-153. doi:10.1177/0193723510366541

Massengale, J. D., \& Farrington, S. K. (1977). The influence of playing position centrality on the careers of college football coaches. Review of Sport and Leisure, 2, 107-115.

McBay, S. (1992). The condition of African American education: Changes and challenges. In J. Dewart (Ed.), The state of Black America 1992 (pp. 141-156). New York, NY: National Urban League.

McDonald, M. G., \& Birrell, S. (1998). Reading sport: Historical articulations of a method. Las Vegas, NV: North American Society for the Sociology of Sport.

Medoff, M. (1977). Position segregation and professional baseball International Review of Sport Sociology, 12, 49-54.

Mills, C. W. (1959). The sociological imagination. New York: Oxford University Press

NCAA (2009). NCAA student-athlete ethnicity report 1999-20002007-2008. URL (last checked 29 March 2012).

http://www.ncaapublications.com/productdownloads/SAEREP09.pdf

NCAA (2010). Trends in graduation success rates and federal graduation rates at NCAA division I institutions. URL (last checked on 29 March 2012).

http://www.ncaa.org/wps/wcm/connect/f015f6004477d89f977cb749 973c7da7/GSR+and+Fed+Trends+for+Web10_26_10+Final.pdf?M OD=AJPERES\&CACHEID=f015f6004477d89f977cb749973c7da7

NCAA (2011a). About the NCAA. URL (last checked on 29 March 2012).

http://www.ncaa.org/wps/wcm/connect/public/ncaa/about+the+ncaa

NCAA (2011b). NCAA best practices: Achieving excellence through diversity and inclusion. URL (last checked 29 March 2012). http://www.ncaa.org/wps/wcm/connect/c166120041b6686e9878b99c c9880460/Achieving+Excellence.pdf?MOD=AJPERES\&CACHEID =c166120041b6686e9878b99cc9880460

NCAA (2011c). Trends in graduation success rates and federal graduation rates at NCAA division I institutions. URL (last checked 29 March 2012).

http://www.ncaa.org/wps/wcm/connect/public/NCAA/PDFs/2011/Tr ends+in+Graduation-Success+Rates+and+Federal+Graduation+Rate $\mathrm{s}+\mathrm{at}+\mathrm{NCAA}+$ Division+I+Institutions

NCAA (2012). Finances: Revenue. URL (last checked 29 March 2012). http://www.ncaa.org/wps/wcm/connect/public/NCAA/Finances/Reve nue

NCES (2007). Digest of Education Statistics 2007 (NCES 2007-002). US Department of Education. URL (last checked on 17 February 2012). http://nces.ed.gov/pubs2007/2007039.pdf 
NCES (2009). Status and trends in the education of racial and ethnic minorities. US Department of Education. URL (last checked on 17 February 2012).

http://nces.ed.gov/pubs2010/2010015/tables/table_24_1.asp

Nettles, M. T., \& Perna, L. W. (1997a). Higher and adult education. The African American Education Data Book (Vol. 1). Fairfax, VA: Frederick D. Patterson Research Institute of the College Fund/ UNCF.

Nettles, M. T., \& Perna, L. W. (1997b). Preschool through high school. The African American Education Data Book (Vol. 2). Fairfax, VA: Frederick D. Patterson Research Institute of the College Fund/ UNCF.

Orfield, G. (2009). Reviving the goal of an integrated society: A 21st century challenge. Los Angeles, CA: The Regents of the University of California.

Palmer, R. T., \& Gasman, M. (2008). It takes a village to raise a child: The role of social capital in promoting academic success for African American men at a Black college. Journal of College Student Development, 49, 52-70. doi:10.1353/csd.2008.0002

Pascarella, E. T., Bohr, L., Nora, A., \& Terenzini, P. T. (1995). Intercollegiate athletic participation and freshman-year cognitive outcomes. Journal of Higher Education, 66, 369-387. doi:10.2307/2943793

Polite, F., \& Hawkins, B. (2011). Sport, race, activism, and social change: The impact of Dr. Harry Edwards' scholarship and service San Diego, CA: Cognella.

Purdy, D. A., Eitzen, D. S., \& Hufnagel, R. (1985). Are athletes also students? The educational attainment of college athletes. In D. Chu, J. O. Segrave, \& B. J. Becker (Eds.), Sport and Higher Education (pp. 221-234). Champaign, IL: Human Kinetics.

Rhoden, W. C. (1989). Many Black college student-athletes express feelings of isolation (Special Issue). URL (last checked on 5 February 2012).

http://query.nytimes.com.gst/fullpage.html?res=950DE1DB1431F93 5757C096F948260\&sec=\&spon=\&pagewanted $=1$

Richardson, L. (1997). Fields of play: Constructing an academic life. New Brunswick, NJ: Rutgers University Press.

Roebuck, J. B., \& Murty, K. B. (1993). Historically Black colleges and univerisities: Their place in Amerian higher education. Westport, CT: Bergin and Garvey.

Sack, A., \& Staurowsky, E. J. (1998). College athletes for hire: The evolution and legacy of the NCAA's amateur myth. Westport, CT: Praeger.

Sage, G. H. (1998). Power and ideology in American sport (2nd ed.). Champaign, IL: Human Kinetics.

Sage, G. H. (2000). Introduction. In D. Brooks, \& R. Althouse (Eds.), Racism in college athletics: The African American athlete's experience (Vol. 2, pp. 2-12). Morgantown, WV: Fitness Information Technology.

Sailes, G. (1993). An investigation of campus stereotypes: The myth of black athletic superiority and the dumb jock stereotype. Sociology of Sport Journal, 10, 88-97.

Sailes, G. (2010). The African American athlete: Social myths and stereotypes. In G. Sailes (Ed.), Modern sport and the African American athlete experience (pp. 55-68). San Diego, CA: Cognella.

Schwaneger, H. (1969). The history of higher education in Deleware. Ph.D. Dissertation, Philadelphia: University of Pennsylvania.

Sellers, R. M. (1992). Racial differences in the predictors for academic achievement of student-athletes in division I revenue producing sports. Sociology of Sport Journal, 9, 48-59.

Sellers, R. M. (2000). African American student-athletes: Opportunity or exploitation? In D. A. Brooks, R. (Ed.), Racism in college athletics: The African American athlete's experience (2nd ed., pp. 133-154). Morgantown, WV: Fitness Information Technology, Inc.

Shapiro, T. M., Meschede, T., \& Sullivan, L. (2010). The racial wealth gap increases fourfold. In I. O. A. A. S. Policy (Ed.), Research and policy brief. Waltham, MA: Brandeis University.

Shropshire, K. (1997). Colorblind propostions: Race, the SAT \& the NCAA. Stanford Law and Policy Review, 8, 141-157.

Shulman, J., \& Bowen, W. (2001). The game of life: College sports and educational values. Princeton, NJ: Princeton University Press.
Singer, J. N. (2005). Understanding racism through the eyes of African-American male student-athletes. Race, Ethnicity, and Education, 8, 365-386.

Singer, J. N. (2008). Benefits and detriments of African American male athletes' participation in a big-time college football program. International Review for the Sociology of Sport, 43, 399-408. doi:10.1080/13613320500323963

Smith, E. (2009). Race, sport and the American dream (2nd ed.). Durham, NC: Carolina Academic Press. doi:10.1177/1012690208099874

Spencer, N. E. (2010). Beyond the sociological imagination: Doing autoethnography to explore intersections of biography and history. In E. Smith (Ed.), Sociology of sport and social theory. Champaign, IL: Human Kinetics.

Steele, C. M., \& Aronson, J. (1995). Stereotype threat and the intellecttual test performance of African Americans. Journal of Personality and Social Psychology, 69, 797-811. doi:10.1037/0022-3514.69.5.797

Stone, A. H. (1908). Is race friction between Whites and Blacks growing and inevitable? American Journal of Sociology, 13, 677. doi:10.1086/211624

US Bureau of the Census (1982). Characteristics of the population below the poverty level: 1980. Washington, DC: US Government Printing Office.

US Bureau of Census (2012). State and county quickfacts. Population Estiamtes, American Community Survey, Census of Population and Housing, State and County Housing Unit Estimates, County Business Patterns, Nonemployer Statistics, Economic Census, Survey of Business Owners, Building Permits, Consolidated Federal Funds Report. URL (last checked on 17 February 2012). http://quickfacts.census.gov/qfd/states/00000.html

US Department of Commerce (1993). We the Americans: Blacks. In E. A. S. Administration (Ed.), Washington, DC: US Bureau of Statistics.

Van Evrie, J. H. (1870). White supremacy and Negro subordination. New York: Van Evrie, Horton \& Co.

Walther, E. S. (1994). Some readings on historically black colleges and universities. Greensboro, NC: Management Information and Research.

Watson, J. C. (2006). Student-athletes and counseling: Factors influencing the decision to seek counseling services. College Student Journal, 40, 35-42.

Wiggins, D. K. (1991). Prized performers but frequently overlooked as students. Research Quarterly for Exercise and Sport, 62, 164-177.

Wiggins, D. K. (2000). Critical events affecting racism in athletics. In D. Brooks, \& R. Althouse (Eds.), Racism in college athletics: The African American athlete's experience (2nd ed., pp. 15-36). Morgantown, WV: Fitness Information Technology.

Wiggins, D. K., \& Miller, P. (2003). The unlevel playing field: A documentary history of the African-American experience in sport. Urbana, IL: University of Illinois Press.

Willie, C. V., Grady, M. K., \& Hope, R. O. (1991). African-Americans and the doctoral experience: Implications for policy. New York: Teachers College.

Wilson, W. J. (1978). The declining significance of race: Blacks and changing American institutions. Chicago, IL: University of Chicage Press.

Wilson, R. (1994). The participation of African Americans in Amerian higher education. In M. Justiz, R. Wilson, \& L. Bjork (Eds.), Minorities in higher education (pp. 195-209). Phoenix: American Council on Education and the Orys Press.

Wilson, C. A. (1996). Racism: From slavery to advanced capitalism. Thousand Oaks, CA: Sage.

Wolff, A., \& Keteyian, A. (1990). Raw recruits: The high stakes game colleges play to get their basketball stars-And what it costs to win. New York, NY: Pocket Books.

Woods, R. (2011). Social issues in sport. Champaign, IL: Human Kinetics.

Wright-Edelman, M. (1988). Growing up in Black America. In J. H. Skolnick, \& E. Currie (Eds.), Crisis in American institutions (p. 154). Glenview, IL: Scott, Foresman.

Zimbalist, A. (2001). Unpaid professionals. Princeton, NJ: Princeton University Press. 